\title{
Usefulness of the Corporate Annual Reports: Evidence from Dhaka Stock Exchange
}

\author{
Md. Abdullah Babu ${ }^{1 *}$, Md. Muktadir Hossain² \\ ${ }^{1}$ Lecturer, School of Business \& Economics, United International University, Madani Avenue, Dhaka-1212, BANGLADESH \\ ${ }^{2}$ Assistant Manager, KPMG, BANGLADESH \\ *E-mail for correspondence: abdullahbabu03@gmail.com
}

https://doi.org/10.18034/abr.v9i1.242

\begin{abstract}
Investors often make decisions based on information provided through different sources such as Corporate Annual Reports, Corporate news, and other media. This study is undertaken to examine the usefulness aspect of the corporate annual reports. A primary dataset composed of 38 participants of which 30 people were general investors and 8 people were stockbrokers was collected through a questionnaire survey. The study has found out that general investors perceive corporate annual reports, newspaper news, and media reviews are as the most significant sources of information. On the other hand, the study has established that stockbrokers consider company annual reports, interim reports, newspaper and media news, stock market publication, and technical analysis as the important sources of information. Also, to the general investors, most significant components of the annual reports are audit committee report, balance sheet, income statement, and statement of changes in equity, and 3 or 5-year reviews (including useful ratios). To the stockbrokers, the most essential components of the annual report are auditor's report to shareholders, balance sheet, income statement, and balance sheet notes. General investors read the balance sheet and income statement more thoroughly than any other components of annual reports. Stockbrokers read auditor's report to shareholders, balance sheet, income statement, balance sheet notes, and income statement notes more thoroughly than any other components of annual reports.
\end{abstract}

Key words: Corporate Annual Report, Investment Decision, General Investors, Stock Brokers

\section{INTRODUCTION}

The sole purpose of the annual reports is to assist users in making economic decisions. However, question and doubt arise regarding the use of annual reports. Also, there are questions relating to the worth and utility of the corporate annual reports. Besides, there are no established facts relating to which aspects of the annual report are more useful to the investors and which aspects are less significant to them. Due to this, it often becomes a difficult job for the investors to differentiate between the relevant information ad irrelevant information. Moreover, they need to make sure that they are not using misleading information. The investment decisions made by them are very crucial and can cause damage to their lives if make decisions without due diligence and careful analysis. Therefore, this study has been undertaken to examine the usefulness of the corporate annual reports.

\section{Aims and Objectives}

This study attempts to achieve the following aims and objectives:
- To determine whether the users read the annual reports while making decisions.

- To determine the important sources of information used by the users.

- To identify users perception about the importance of different components of an annual report.

- To evaluate how thoroughly users read different components of an annual report.

- To offer recommendations for improving corporate reporting in Bangladesh.

\section{LITERATURE REVIEW}

One of the pioneering studies to have attempted to discover the information needs and sources of such information was undertaken in the United States by Baker \& Haslem (1973). The authors found that the majority of individual investors rely heavily on stockbroker's advice as their major sources of information about companies. Financial statements, however, were found to be a source 
of information by an only minority of individual investors. With respect to other information items that are expected to be disclosed by companies, Baker \& Haslem (1973) pointed out that individual investors assign a high value to the information that highlights future prospects of a company. At the same time, individual investors attribute a much lower degree of importance to the information regarding dividends. In the United Kingdom, Lee \& Tweedie (1975) found the chairman's report to be the most widely read followed by the profit and loss account. This was credited to the simplicity of the chairman's report, which explains the more technical information contained in other parts of the report. However, Alattar \& Al-Khater (2008) found that users view annual reports to be a useful and significant source of information for making investment decisions. They have also established that users treat balance sheet, auditor's report, cash flow statement, income statement and notes to the accounts as the most essential and easily comprehensible sections in the annual reports. In addition to that, they have also found out that users also rely on government publications and newspapers, magazines and journals to obtain up to date information. Moreover, Day (1986) and Yap (1997) identified that cash flow statements have recently become significant sources of information for users. Contrasting results were obtained in a study by Naser et al. (2003) where the authors found that the users view annual reports to be the second most significant source of information for making investment decisions. However, they pointed out that institutional users are more reliant on annual reports for making decisions regarding investment. The effect of annual reports in lending decisions has also been observed by Kitindi et al. (2007). An empirical study conducted by Kitindi et al. (2007) suggests that income statement and other information in corporate annual reports are the major sources of information to the lenders. However, contrasting results were found by Abu-Nassar \& Rutherford (1996) who concluded that Jordanian Bank Officers prefer income statement and the balance sheet over any other parts of the corporate annual reports. Likewise, Al-Razeen \& Karbhari (2004) established that the balance sheet and the income statement were the most significant elements of corporate annual reports to Saudi Arabian users. Anderson \& Epstein (1995) extended their research by providing a useful investigation on Australia. The authors highlight the directors' report to be the most thoroughly read followed by the income statement. Nevertheless, their respondents did perceive the income statement to be more useful than the directors' report in making an investment decision. Anwar et al. (2012) analyzed the use and effectiveness of Annual reports and the help which they yield to Financial Analysts, Creditors and Investors for their decisions and how much reliance they can have on Annual reports for Investment and Finance Decisions. This study was both empirical and descriptive in nature and performed the statistical testing of data collected from a developing country's (Pakistan) investors, creditors and financial analysts. The results after doing statistical analysis indicated that Annual reports were not only useful for all user categories but also a much relied upon tool for investment and finance decisions. There are some dissenting views regarding the usefulness of annual reports in which it was suggested that annual reports are of no or restricted use. Magness (2003) for example, raised questions regarding the usefulness of financial statements by pointing out that financial statements leave out environmental values.

\section{Research Methodology and Design}

This study is mainly a quantitative study. For the purpose of the study, quantitative data are collected and analyzed. Primary data were collected through a survey questionnaire. The questionnaire included close-ended questions. A 5 point Likert scale is used for constructing the questionnaire. The data are collected from a sample of 38 respondents who were selected based on convenient sampling. Among the respondents, 30 people are the general investors in Bangladesh and the other 8 are the stockbrokers working in brokerage houses in Dhaka.

The following brokerage houses were approached to collect data:

1. Sinha Securities Ltd, Dhanmondi, Dhaka

2. MTB Securities Ltd, Motijheel, Dhaka

3. BRAC EPL, Motijheel, Dhaka

4. First Capital Securities Ltd. Dhaka

Data are evaluated using SPSS software. Data have been scrutinized and presented through frequency distribution, graphs, descriptive statistics, and hypothesis testing.

\section{Results AND ANALYSIS}

\section{Demographics}

Figure 1: Types of Respondents

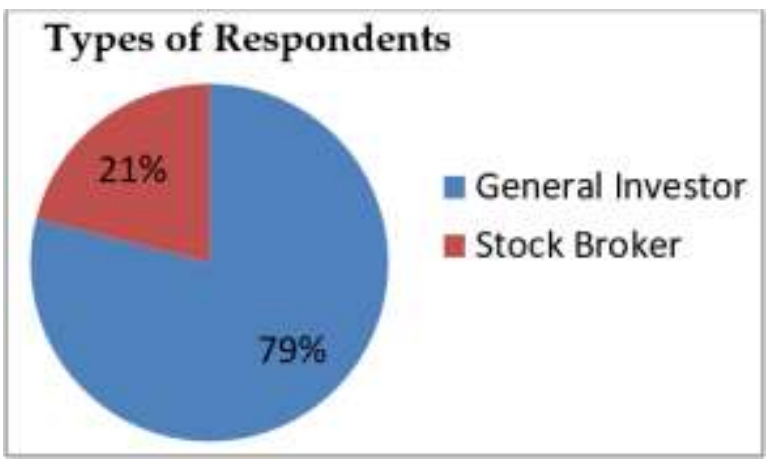

Figure 1 shows that $79 \%$ of the participants are general investors and that the remaining $21 \%$ of the participants are stock brokers. 
Figure 2: Having Accounting \& Finance Course

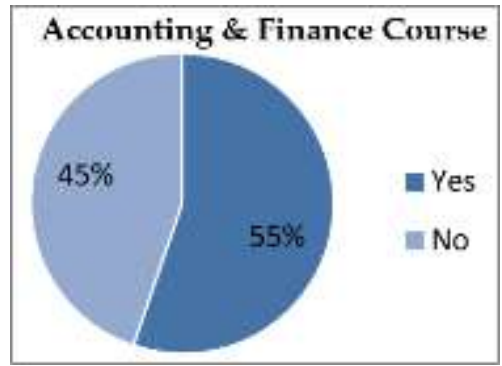

The above graph (figure-2) demonstrates that of the total participants $55 \%$ obtained a course on accounting and finance. Figure- 2 also shows that $45 \%$ of the participants did not have any course in finance and accounting.

Figure 3: Training

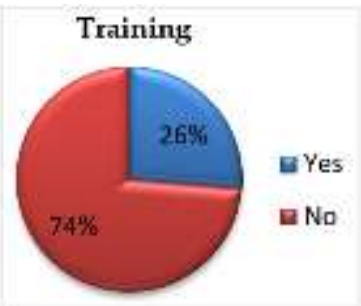

The graph above clearly shows that $74 \%$ of the participants did not receive any formal training on the stock market and the $26 \%$ did receive training on the stock market

Figure 4: Educational Qualifications

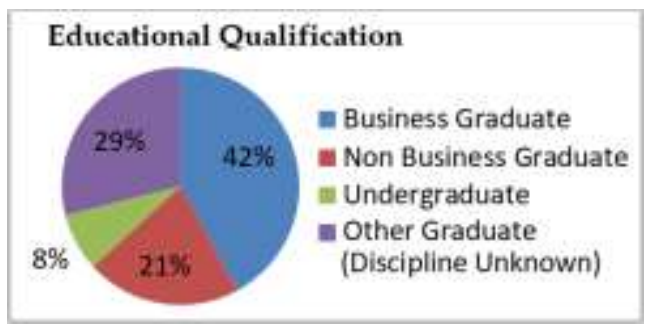

The participants have varied academic qualifications. Figure- 5 demonstrates that the majority of the participants are business graduate representing $42 \%$ of the sample. $29 \%$ of the participants are graduates from an unknown discipline. Undergraduate students make up $8 \%$ of the participants, and $21 \%$ don't have any business degree.

Figure 6: Occupation

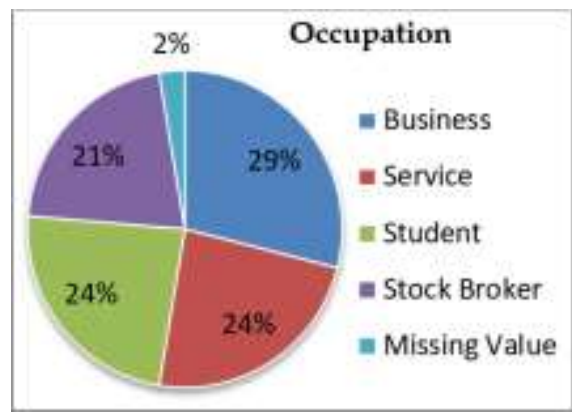

Participants are affiliated with different occupations. Majority of the participants are engaged in business. An equal portion of the participants is involved in the service industry and study. However, $2 \%$ of the participants refrained from disclosing their occupation.

Figure 7: Experience

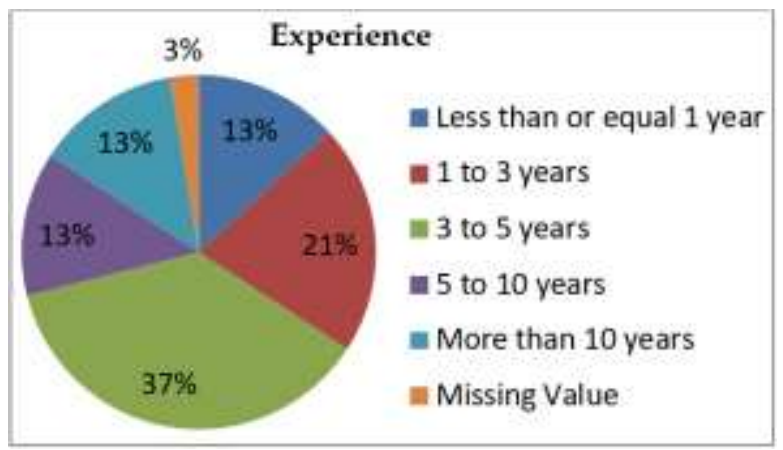

When it comes to experience in dealing with the stock market, the majority of the participants have decent experience in dealing with the stock market. The above graph shows that $71 \%$ of the total participants have at least 1 year of familiarity. However, $13 \%$ of them have less than 1-year experience and 3\% did not choose to disclose their level of involvement in this field.

\section{Descriptive Statistics}

\section{Reading Annual Reports for decision making}

In the case of reading annual reports for decision making, the overall mean is 3.24 . However, the mean varies with respect to different types of respondents, and their other characteristics.

Table 1: Comparing Mean in terms of different types of respondents

\begin{tabular}{|l|l|c|c|c|}
\hline $\begin{array}{l}\text { Reading Annual } \\
\text { Reports for } \\
\text { decision making }\end{array}$ & & Overall & \multicolumn{2}{|c|}{$\begin{array}{c}\text { Types of } \\
\text { Respondents }\end{array}$} \\
\cline { 3 - 5 } & & & $\begin{array}{c}\text { General } \\
\text { Investors }\end{array}$ & Broker \\
\cline { 2 - 5 } & Mean & 3.24 & 2.93 & 4.38 \\
\hline
\end{tabular}

It can be concluded from the above table that the stockbrokers, by virtue of their training and experiences, can utilize the annual reports in decision making more usefully.

Table 2: Comparing Mean in terms of attendance in training

\begin{tabular}{|l|l|c|c|c|}
\hline Reading Annual & & Overall & \multicolumn{2}{|c|}{ Training Attended } \\
\cline { 4 - 5 } $\begin{array}{l}\text { Reports for } \\
\text { decision making }\end{array}$ & & & Yes & No \\
\cline { 2 - 5 } & Mean & 3.24 & 4.30 & 2.85 \\
\hline
\end{tabular}

Perhaps, training helps the users to understand the importance of reading annual reports while making decisions. Thus, trained people read annual reports for decision making more than those who are not trained. 
Table 3: Comparing Mean in terms of attendance in courses

\begin{tabular}{|l|c|c|c|c|}
\hline Reading Annual & & Overall & \multicolumn{2}{|c|}{ Course Attended } \\
\cline { 3 - 5 } $\begin{array}{l}\text { Reports for } \\
\text { decision making }\end{array}$ & & & Yes & No \\
\cline { 2 - 5 } & Mean & 3.24 & 3.00 & 3.53 \\
\hline
\end{tabular}

Unlike training, accounting or finance courses leading people to read annual reports less than those didn't have any such courses. Perhaps, the courses were not effective enough to make them realize the usefulness of reading annual reports. Another probable reason can be that people having such courses know exactly which figures are useful; thus, they do not have to read full annual reports for decision making. A third explanation can be that, perhaps, people having courses, emphasize on interim reports more than they do on annual reports for making decisions.

Table 4: Comparing Mean in terms of different level of education

\begin{tabular}{|l|l|c|}
\hline Reading & Level of education & Means \\
\cline { 2 - 3 } Annual & Business Graduate & 3.12 \\
\cline { 2 - 3 } $\begin{array}{l}\text { Reports for } \\
\text { decision } \\
\text { making }\end{array}$ & Non-Business Graduate & 3.50 \\
\cline { 2 - 3 } & Undergraduate & 3.00 \\
\cline { 2 - 3 } & $\begin{array}{l}\text { Other Graduate (Discipline } \\
\text { Unknown) }\end{array}$ & 3.30 \\
\hline
\end{tabular}

The outcome shows that the non-business graduates are more likely to read the annual reports for decision making. The probable reason can be that they have a lesser understanding of the annual report. Thus, they read more and more to understand them and to use them in decision making.

Table 5: Comparing Mean in terms of different occupations

\begin{tabular}{|l|l|c|}
\hline Reading Annual Reports & Occupations & Means \\
\cline { 2 - 3 } for decision making & Business & 2.64 \\
\cline { 2 - 3 } & Service & 3.22 \\
\cline { 2 - 3 } & Student & 3.00 \\
\cline { 2 - 3 } & Stock Broker & 4.38 \\
\hline
\end{tabular}

The outcome shows that the means are close to each other except for that of the stockbroker. Perhaps, the reason is that most of the respondents of this study who have training are the stock brokers.

Table 6: Comparing Mean in terms of different level of experience

\begin{tabular}{|l|l|c|}
\hline \multirow{4}{*}{$\begin{array}{l}\text { Reading Annual } \\
\text { Reports for }\end{array}$} & Level of Experience & Mean \\
\cline { 2 - 3 } decision making & Less or equal 1 year & 2.40 \\
\cline { 2 - 3 } & 1 to 3 years & 2.88 \\
\cline { 2 - 3 } & 3 to 5 year & 3.29 \\
\cline { 2 - 3 } & 5 to 10 years & 4.00 \\
\cline { 2 - 3 } & More than 10 years & 3.80 \\
\hline
\end{tabular}

This outcome shows an interesting pattern that the higher the level of experience, the higher the level of reading annual reports while making investment decisions.

\section{Importance of the Sources of Information}

Table 7: Analysis of means for sources of information

\begin{tabular}{|c|c|c|c|c|c|c|c|c|}
\hline \multirow[t]{2}{*}{ Sources } & \multirow{2}{*}{$\begin{array}{l}\text { Overall } \\
\text { Means }\end{array}$} & \multirow[t]{2}{*}{ Rank } & \multicolumn{2}{|c|}{ Types of Respondents } & \multicolumn{2}{|c|}{ Course Attended } & \multicolumn{2}{|c|}{ Training Attended } \\
\hline & & & General Investors & Brokers & Yes & No & Yes & No \\
\hline Stock Broker's Advice & 3.26 & 05 & 3.27 & 3.25 & 3.14 & 3.41 & 3.40 & 3.21 \\
\hline Family Friend's advice & 3.05 & 08 & 3.17 & 2.62 & 3.19 & 2.88 & 2.80 & 3.14 \\
\hline Company annual report & 3.87 & 02 & 3.70 & 4.50 & 3.95 & 3.76 & 4.50 & 3.64 \\
\hline Interim Reports & 3.68 & 03 & 3.40 & 4.75 & 3.76 & 3.59 & 4.70 & 3.32 \\
\hline Communication with management & 2.55 & 09 & 2.30 & 3.50 & 2.57 & 2.53 & 3.60 & 2.18 \\
\hline $\begin{array}{l}\text { Newspaper news and } \\
\text { media reviews }\end{array}$ & 3.89 & 01 & 3.90 & 3.88 & 3.71 & 4.12 & 3.80 & 3.93 \\
\hline Stock market publications & 3.24 & 06 & 2.97 & 4.25 & 3.14 & 3.35 & 3.90 & 3.00 \\
\hline Technical Analysis & 3.27 & 04 & 2.97 & 4.57 & 3.10 & 3.50 & 4.22 & 2.96 \\
\hline Information on the Internet & 3.08 & 07 & 3.07 & 3.12 & 2.86 & 3.35 & 3.20 & 3.04 \\
\hline Rumors & 2.11 & 11 & 2.20 & 1.75 & 2.10 & 2.12 & 1.80 & 2.21 \\
\hline Others & 2.37 & 10 & 2.06 & 4.00 & 2.78 & 2.00 & 4.25 & 1.87 \\
\hline
\end{tabular}

The above-mentioned outcomes show that the users ranked newspaper news and media reviews followed by Company annual report, and Interim Reports. However, the crosscomparison of means shows different outcomes. The red cells show that the mean value for General investors and Brokers are not closer in most cases given that the number of the broker was very small. For the purpose of simplification of the analysis, means having any difference less than 0.50 is considered relatively closer. To the general investors, newspaper news and media reviews, Company annual report, and Interim Reports are the key sources of information. To the stockbrokers' Company annual report, Interim Reports, Technical Analysis, Stock market publications, and other sources are the most imperative sources of information. In case of finance or accounting courses, all most all of the means were closer for both types of users having or not having courses. However, having or not having training resulted in the major difference in several 
of the means. This outcome is consistent with the previous outcome that training and types of respondents created major differences in means while finance or accounting courses have little effect on the means. However, these are pretest values. Hypothesis testing of these differences may not produce exactly similar results.

\section{The degree of importance of Components of Annual Reports}

Table 8: Analysis of means for Degree of importance of Components of Annual Reports

\begin{tabular}{|c|c|c|c|c|c|c|c|c|}
\hline \multirow[t]{2}{*}{ Sources } & \multirow{2}{*}{$\begin{array}{l}\text { Overall } \\
\text { Means }\end{array}$} & \multirow[t]{2}{*}{ Rank } & \multicolumn{2}{|c|}{ Types of Respondents } & \multicolumn{2}{|c|}{ Course Attended } & \multicolumn{2}{|c|}{ Training Attended } \\
\hline & & & General Investors & Brokers & Yes & No & Yes & No \\
\hline Company's Information & 3.14 & 10 & 2.93 & 4.00 & 3.20 & 3.06 & 3.89 & 2.89 \\
\hline Chairman's review & 2.65 & 15 & 2.53 & 3.14 & 2.70 & 2.59 & 3.11 & 2.50 \\
\hline Director's Report & 2.76 & 13 & 2.57 & 3.57 & 2.90 & 2.59 & 3.44 & 2.54 \\
\hline Corporate Governance Statement & 2.92 & 11 & 2.80 & 3.50 & 3.05 & 2.75 & 3.50 & 2.75 \\
\hline Audit Committee Report & 3.58 & 05 & 3.53 & 3.83 & 3.75 & 3.38 & 4.00 & 3.46 \\
\hline Auditor's Report to shareholders & 3.54 & 06 & 3.23 & 4.86 & 3.35 & 3.76 & 4.89 & 3.11 \\
\hline Balance Sheet & 4.38 & 01 & 4.33 & 4.57 & 4.35 & 4.41 & 4.44 & 4.36 \\
\hline Income Statement & 4.35 & 02 & 4.30 & 4.57 & 4.30 & 4.41 & 4.44 & 4.32 \\
\hline Statement of Changes in Equity & 3.69 & 04 & 3.73 & 3.50 & 3.79 & 3.59 & 3.50 & 3.75 \\
\hline Cash flow Statement & 3.47 & 07 & 3.43 & 3.67 & 3.26 & 3.71 & 3.50 & 3.46 \\
\hline Accounting Policy notes & 2.69 & 14 & 2.73 & 2.50 & 2.84 & 2.53 & 2.88 & 2.64 \\
\hline Balance Sheet notes & 3.25 & 08 & 3.14 & 3.71 & 3.47 & 3.00 & 3.67 & 3.11 \\
\hline Income Statement notes & 3.16 & 09 & 3.07 & 3.57 & 3.35 & 2.94 & 3.33 & 3.11 \\
\hline Cash flow Statement notes & 2.84 & 12 & 2.73 & 3.29 & 2.95 & 2.71 & 3.33 & 2.68 \\
\hline Value Added Statement & 2.51 & 16 & 2.30 & 3.43 & 2.55 & 2.47 & 3.33 & 2.25 \\
\hline Environmental Report & 2.32 & 18 & 2.20 & 2.86 & 2.20 & 2.47 & 2.78 & 2.18 \\
\hline $\begin{array}{l}3 \text { or } 5 \text {-year reviews } \\
\text { (including useful ratios) }\end{array}$ & 3.94 & 03 & 3.93 & 4.00 & 3.85 & 4.06 & 3.88 & 3.96 \\
\hline Essay and pictorial on operations & 2.33 & 17 & 2.28 & 2.57 & 2.16 & 2.53 & 2.56 & 2.26 \\
\hline
\end{tabular}

Users ranked Balance Sheet as the most significant components of the annual report followed by Income Statement, 3 or 5-year reviews (including useful ratios), Statement of Changes in Equity, and Audit Committee Report. Auditor's Report to shareholders and Cash flow Statement were ranked as 6th and 7th respectively. To the General investors, the most crucial components of annual reports are Balance Sheet, Income Statement, 3 or 5-year reviews (including useful ratios), Statement of Changes in
Equity, and Audit Committee Report. However, to the stockbrokers, the most significant components are Company's Information, Auditor's Report to shareholders, Balance Sheet, Income Statement, 3 or 5-year reviews (including useful ratios). In case of cross-comparison of the means, the previous pattern has remained consistent. Thus, training and types of respondents created major differences in means while finance or accounting courses had little effect on the means.

\section{The degree of thoroughness in reading}

Table 9: Analysis of means for Degree of thoroughness in reading

\begin{tabular}{|c|c|c|c|c|c|c|c|c|}
\hline \multirow[t]{2}{*}{ Sources } & \multirow{2}{*}{$\begin{array}{l}\text { Overall } \\
\text { Means }\end{array}$} & \multirow[t]{2}{*}{ Rank } & \multicolumn{2}{|c|}{ Types of Respondents } & \multicolumn{2}{|c|}{ Course Attended } & \multicolumn{2}{|c|}{ Training Attended } \\
\hline & & & General Investors & Brokers & Yes & No & Yes & No \\
\hline Company's Information & 2.94 & 10 & 2.73 & 3.86 & 3.15 & 2.71 & 3.78 & 2.68 \\
\hline Chairman's review & 2.76 & 12 & 2.50 & 3.75 & 2.95 & 2.53 & 3.60 & 2.46 \\
\hline Director's Report & 2.71 & 13 & 2.53 & 3.38 & 2.86 & 2.53 & 3.30 & 2.50 \\
\hline Corporate Governance Statement & 2.78 & 11 & 2.57 & 3.83 & 3.05 & 2.44 & 3.63 & 2.54 \\
\hline Audit Committee Report & 3.18 & 07 & 2.97 & 4.00 & 3.19 & 3.18 & 4.00 & 2.89 \\
\hline Auditor's Report to shareholders & 3.39 & 06 & 3.07 & 4.62 & 3.24 & 3.59 & 4.40 & 3.04 \\
\hline Balance Sheet & 3.95 & 02 & 3.77 & 4.62 & 3.86 & 4.06 & 4.40 & 3.79 \\
\hline Income Statement & 4.03 & 01 & 3.87 & 4.62 & 4.10 & 3.94 & 4.50 & 3.86 \\
\hline Statement of Changes in Equity & 3.43 & 04 & 3.37 & 3.71 & 3.40 & 3.47 & 3.44 & 3.43 \\
\hline Cash flow Statement & 3.41 & 05 & 3.23 & 4.14 & 3.20 & 3.65 & 4.11 & 3.18 \\
\hline Accounting Policy notes & 2.50 & 15 & 2.52 & 2.43 & 2.68 & 2.29 & 2.56 & 2.48 \\
\hline
\end{tabular}




\begin{tabular}{|l|l|l|l|l|l|l|l|l|}
\hline Balance Sheet notes & 3.11 & 08 & 2.90 & 3.88 & 3.33 & 2.82 & 3.50 & 2.96 \\
\hline Income Statement notes & 2.95 & 09 & 2.77 & 3.62 & 3.19 & 2.65 & 3.40 & 2.79 \\
\hline Cash flow Statement notes & 2.65 & 14 & 2.48 & 3.25 & 2.85 & 2.41 & 3.10 & 2.48 \\
\hline Value Added Statement & 2.46 & 16 & 2.24 & 3.25 & 2.40 & 2.53 & 3.00 & 2.26 \\
\hline Environmental Report & 2.17 & 18 & 2.00 & 2.75 & 2.05 & 2.31 & 2.60 & 2.00 \\
\hline 3 or 5-year reviews (including useful ratios) & 3.47 & 03 & 3.41 & 3.71 & 3.33 & 3.67 & 3.44 & 3.48 \\
\hline Essay and pictorial on operations & 2.24 & 17 & 2.11 & 2.71 & 1.94 & 2.56 & 2.44 & 2.16 \\
\hline
\end{tabular}

In case of the degree of thoroughness in reading, users ranked Income Statement first followed by Balance Sheet, 3 or 5-year reviews, Statement of Changes in Equity, and Cash flow Statement. General investors read Balance Sheet, 3 or 5-year reviews, Statement of Changes in Equity, and Cash flow Statement, Auditor's Report to shareholders more thoroughly while stockbrokers read Audit Committee Report, Auditor's Report to shareholders, Balance Sheet, Income Statement, Cash flow Statement, Balance Sheet notes more thoroughly. In case of cross-comparison of the means, the previous pattern was intensified in a consistent pattern. Here, training and types of respondents created major differences in most of the means while finance or accounting courses have created differences in a few of the means.

\section{Hypothesis Testing}

In this section, the hypothesis is tested against the test value 3 with a $95 \%$ confidence level. Here, 'Mean-3=0' indicates the null hypothesis. However, the alternative hypothesis is 'Mean $\neq 3^{\prime}$.

Thus, the null hypothesis is rejected where Sig. (2-tailed) are less than 0.05 .

\section{Hypothesis 1}

$\mathrm{H}_{0}$ : Mean for reading the annual reports for decision making is not different from 3

$\mathrm{H}_{1}$ : Mean for reading the annual reports for decision making is different from 3

Table 10: Reading annual reports for decision making (General investors)

\begin{tabular}{|l|c|c|c|c|c|c|}
\hline General investors & $\mathrm{N}$ & Mean & $\mathrm{t}$ & $\mathrm{df}$ (degrees of freedom) & Sig. (2-tailed) & Interpretation \\
\hline Reading annual reports for decision making & 29 & 2.93 & -.372 & 28 & .712 & $\begin{array}{c}\text { Not } \\
\text { significant }\end{array}$ \\
\hline
\end{tabular}

Table 11: Reading annual reports for decision making (Stock Broker)

\begin{tabular}{|c|c|c|c|c|c|c|}
\hline Stock Broker & $\mathrm{N}$ & Mean & $\mathrm{t}$ & Df (degrees of freedom) & Sig. (2-tailed) & Interpretation \\
\hline Reading annual reports for decision making & 8 & 4.38 & 4.245 & 7 & .004 & Significant \\
\hline
\end{tabular}

This outcome indicates that the general investors somewhat read annual reports for decision making. However, the stockbrokers read annual reports other than somewhat for decision making.

\section{Hypothesis 2}

$\mathrm{H}_{0}$ : Mean for various sources of information are not different from 3

$\mathrm{H}_{2}$ : Mean for various sources of information are different from 3

Table 12: Sources of information (General Investors)

\begin{tabular}{|l|c|c|c|c|c|c|c|}
\hline $\begin{array}{l}\text { Sources of information } \\
\text { (General Investors ) }\end{array}$ & $\mathrm{N}$ & Mean & $\begin{array}{c}\text { Std. } \\
\text { Deviation }\end{array}$ & $\mathrm{t}$ & $\begin{array}{c}\text { Df (degrees } \\
\text { of freedom) }\end{array}$ & $\begin{array}{c}\text { Sig. } \\
\text { (2-tailed) }\end{array}$ & $\begin{array}{c}\text { Statistical } \\
\text { Significance }\end{array}$ \\
\hline Stock Broker's Advice & 30 & 3.27 & 1.39 & 1.05 & 29 & 0.30 & Not Significant \\
\hline FnF advice & 30 & 3.17 & 1.18 & 0.78 & 29 & 0.44 & Not Significant \\
\hline Company Annual Report & 30 & 3.70 & 1.26 & 3.03 & 29 & 0.01 & Significant \\
\hline Interim Report & 30 & 3.40 & 1.22 & 1.80 & 29 & 0.08 & Not Significant \\
\hline Communication with Management & 30 & 2.30 & 1.44 & -2.66 & 29 & 0.01 & Significant \\
\hline Newspaper and media & 30 & 3.90 & 0.80 & 6.14 & 29 & 0.00 & Significant \\
\hline Stock market publication & 30 & 2.97 & 1.38 & -0.13 & 29 & 0.90 & Not Significant \\
\hline Technical analysis & 30 & 2.97 & 1.47 & -0.12 & 29 & 0.90 & Not Significant \\
\hline Information on the Internet & 30 & 3.07 & 1.51 & 0.24 & 29 & 0.81 & Not Significant \\
\hline Rumors & 30 & 2.20 & 1.24 & -3.53 & 29 & 0.00 & Significant \\
\hline Others & 16 & 2.06 & 1.57 & -2.39 & 15 & 0.03 & Significant. \\
\hline
\end{tabular}


Thus, the test indicates that general investors view company annual reports, newspaper news, and media reviews are as moderately crucial sources of information.

Table 13: Sources of information (Stock Broker)

\begin{tabular}{|l|c|c|c|c|c|c|c|}
\hline $\begin{array}{l}\text { Sources of information } \\
\text { (Stock Broker) }\end{array}$ & $\mathrm{N}$ & Mean & $\begin{array}{c}\text { Std. } \\
\text { Deviation }\end{array}$ & $\mathrm{t}$ & $\begin{array}{c}\text { Df (degrees } \\
\text { of freedom) }\end{array}$ & $\begin{array}{c}\text { Sig. } \\
\text { (2-tailed) }\end{array}$ & $\begin{array}{c}\text { Statistical } \\
\text { Significance }\end{array}$ \\
\hline Stock Broker's Advice & 8 & 3.25 & 1.49 & 0.48 & 7 & 0.65 & Not Significant \\
\hline FnF advice & 8 & 2.62 & 1.30 & -0.81 & 7 & 0.44 & Not Significant \\
\hline Company Annual Report & 8 & 4.50 & 0.76 & 5.61 & 7 & 0.00 & Significant \\
\hline Interim Report & 8 & 4.75 & 0.71 & 7.00 & 7 & 0.00 & Significant \\
\hline Communication with Management & 8 & 3.50 & 1.31 & 1.08 & 7 & 0.32 & Not Significant \\
\hline Newspaper and media & 8 & 3.88 & 0.84 & 2.97 & 7 & 0.02 & Significant \\
\hline Stock market publication & 8 & 4.25 & 1.04 & 3.42 & 7 & 0.01 & Significant \\
\hline Technical analysis & 7 & 4.57 & 1.13 & 3.67 & 6 & 0.01 & Significant \\
\hline Information on the Internet & 8 & 3.12 & 1.73 & 0.21 & 7 & 0.84 & Not Significant \\
\hline Rumors & 8 & 1.75 & 0.89 & -3.99 & 7 & 0.01 & Significant \\
\hline Others & 3 & 4.00 & 1.00 & 1.73 & 2 & 0.23 & Not Significant \\
\hline
\end{tabular}

Stockbrokers consider Company Annual Report, Interim Report, Newspaper and media, Stock market publication, Technical analysis as other than moderately vital sources of information.

\section{Hypothesis 3}

$\mathrm{H}_{0}$ : Mean for components of the annual report are not different from 3

$\mathrm{H}_{3}$ : Mean for components of the annual report are different from 3

Table 14: Importance of the components of the annual report (General Investor)

\begin{tabular}{|l|c|c|c|c|c|c|}
\hline $\begin{array}{l}\text { Importance of the components of the } \\
\text { annual report (General Investor) }\end{array}$ & $\mathrm{N}$ & $\mathrm{Mean}$ & $\mathrm{t}$ & $\begin{array}{c}\text { Df (degrees } \\
\text { of freedom) }\end{array}$ & $\begin{array}{c}\text { Sig. } \\
\text { (2-tailed) }\end{array}$ & $\begin{array}{c}\text { Statistical } \\
\text { Significance }\end{array}$ \\
\hline Company's information & 30 & 2.93 & $\mathbf{- 0 . 2 7}$ & 29 & $\mathbf{0 . 7 9}$ & Not Significant \\
\hline Chairman's review & 30 & 2.53 & $\mathbf{- 2 . 0 0}$ & 29 & $\mathbf{0 . 0 6}$ & Not Significant \\
\hline Director's Report & 30 & 2.57 & $\mathbf{- 2 . 1 5}$ & 29 & $\mathbf{0 . 0 4}$ & Significant \\
\hline Corporate Governance Statement & 30 & 2.80 & $\mathbf{- 0 . 9 7}$ & 29 & $\mathbf{0 . 3 4}$ & Not Significant \\
\hline Audit Committee Report & 30 & 3.53 & $\mathbf{2 . 1 1}$ & 29 & $\mathbf{0 . 0 4}$ & Significant \\
\hline Auditor's Report to shareholders & 30 & 3.23 & $\mathbf{0 . 9 8}$ & 29 & $\mathbf{0 . 3 4}$ & Not Significant \\
\hline Balance Sheet & 30 & 4.33 & $\mathbf{7 . 9 2}$ & 29 & $\mathbf{0 . 0 0}$ & Significant \\
\hline Income Statement & 30 & 4.30 & $\mathbf{8 . 9 6}$ & 29 & $\mathbf{0 . 0 0}$ & Significant \\
\hline Statement of Changes in Equity & 30 & 3.73 & $\mathbf{4 . 2 5}$ & 29 & $\mathbf{0 . 0 0}$ & Significant \\
\hline Cash flow Statement & 30 & 3.43 & $\mathbf{1 . 8 6}$ & 29 & $\mathbf{0 . 0 7}$ & Not Significant \\
\hline Accounting Policy notes & 30 & 2.73 & $\mathbf{- 1 . 2 8}$ & 29 & $\mathbf{0 . 2 1}$ & Not Significant \\
\hline Balance Sheet notes & 29 & 3.14 & $\mathbf{0 . 6 0}$ & 28 & $\mathbf{0 . 5 6}$ & Not Significant \\
\hline Income Statement notes & 30 & 3.07 & $\mathbf{0 . 2 7}$ & 29 & $\mathbf{0 . 7 9}$ & Not Significant \\
\hline Cash flow Statement notes & 30 & 2.73 & $\mathbf{- 1 . 1 9}$ & 29 & $\mathbf{0 . 2 5}$ & Not Significant \\
\hline Value Added Statement & 30 & 2.30 & $\mathbf{- 3 . 2 5}$ & 29 & $\mathbf{0 . 0 0}$ & Significant \\
\hline Environmental Report & 30 & 2.20 & $\mathbf{- 3 . 5 3}$ & 29 & $\mathbf{0 . 0 0}$ & Significant \\
\hline 3 or 5-year reviews (including useful ratios) & 30 & 3.93 & $\mathbf{4 . 1 6}$ & 29 & $\mathbf{0 . 0 0}$ & Significant \\
\hline Essay and pictorial on operations & 29 & 2.28 & $\mathbf{- 3 . 1 2}$ & 28 & $\mathbf{0 . 0 0}$ & Significant \\
\hline
\end{tabular}

To the general investors, most essential components of the annual report are Audit Committee Report, Balance Sheet, Income Statement, and Statement of Changes in Equity, 3 or 5-year reviews (including useful ratios).

Table 15: Importance of the components of the annual report (Stock Broker)

\begin{tabular}{|l|c|c|c|c|c|c|}
\hline $\begin{array}{l}\text { Importance of the components of the } \\
\text { annual report (Stock Broker) }\end{array}$ & $\mathrm{N}$ & $\mathrm{Mean}$ & $\mathrm{t}$ & $\begin{array}{c}\text { Df (degrees } \\
\text { of freedom) }\end{array}$ & $\begin{array}{c}\text { Sig. } \\
\text { (2-tailed) }\end{array}$ & $\begin{array}{c}\text { Statistical } \\
\text { Significance }\end{array}$ \\
\hline Company's Information & 7 & 4.00 & $\mathbf{1 . 8 7}$ & 6 & $\mathbf{0 . 1 1}$ & Not Significant \\
\hline Chairman's review & 7 & 3.14 & $\mathbf{0 . 2 8}$ & 6 & $\mathbf{0 . 7 9}$ & Not Significant \\
\hline Director's Report & 7 & 3.57 & $\mathbf{1 . 3 3}$ & 6 & $\mathbf{0 . 2 3}$ & Not Significant \\
\hline Corporate Governance Statement & 6 & 3.50 & $\mathbf{0 . 8 1}$ & 5 & $\mathbf{0 . 4 6}$ & Not Significant \\
\hline \hline
\end{tabular}




\begin{tabular}{|l|c|c|c|c|c|c|}
\hline Audit Committee Report & 6 & 3.83 & $\mathbf{1 . 2 7}$ & 5 & $\mathbf{0 . 2 6}$ & Not Significant \\
\hline Auditor's Report to shareholders & 7 & 4.86 & $\mathbf{1 3 . 0 0}$ & 6 & $\mathbf{0 . 0 0}$ & Significant \\
\hline Balance Sheet & 7 & 4.57 & $\mathbf{5 . 2 8}$ & 6 & $\mathbf{0 . 0 0}$ & Significant \\
\hline Income Statement & 7 & 4.57 & $\mathbf{5 . 2 8}$ & 6 & $\mathbf{0 . 0 0}$ & Significant \\
\hline Statement of Changes in Equity & 6 & 3.50 & $\mathbf{0 . 8 1}$ & 5 & $\mathbf{0 . 4 6}$ & Not Significant \\
\hline Cash flow Statement & 6 & 3.67 & $\mathbf{1 . 0 9}$ & 5 & $\mathbf{0 . 3 3}$ & Not Significant \\
\hline Accounting Policy notes & 6 & 2.50 & $\mathbf{- 1 . 4 6}$ & 5 & $\mathbf{0 . 2 0}$ & Not Significant \\
\hline Balance Sheet notes & 7 & 3.71 & $\mathbf{2 . 5 0}$ & 6 & $\mathbf{0 . 0 5}$ & Significant \\
\hline Income Statement notes & 7 & 3.57 & $\mathbf{1 . 9 2}$ & 6 & $\mathbf{0 . 1 0}$ & Not Significant \\
\hline Cash flow Statement notes & 7 & 3.29 & $\mathbf{1 . 0 0}$ & 6 & $\mathbf{0 . 3 6}$ & Not Significant \\
\hline Value Added Statement & 7 & 3.43 & $\mathbf{0 . 8 1}$ & 6 & $\mathbf{0 . 4 5}$ & Not Significant \\
\hline Environmental Report & 7 & 2.86 & $\mathbf{- 0 . 3 1}$ & 6 & $\mathbf{0 . 7 7}$ & Not Significant \\
\hline 3 or 5-year reviews (including useful ratios) & 6 & 4.00 & $\mathbf{2 . 2 4}$ & 5 & $\mathbf{0 . 0 8}$ & Not Significant \\
\hline Essay and pictorial on operations & 7 & 2.57 & $\mathbf{- 0 . 8 1}$ & 6 & $\mathbf{0 . 4 5}$ & Not Significant \\
\hline
\end{tabular}

To the stockbrokers, the most significant components of the annual report are Auditor's Report to shareholders, Balance Sheet, Income Statement, and Balance Sheet notes.

\section{Hypothesis 4}

$\mathrm{H}_{0}$ : Mean for reading the components of annual report thoroughly are not different from 3

$\mathrm{H}_{4}$ : Mean for reading the components of annual report thoroughly are different from 3

Table 16: Thoroughness of reading the annual report (General Investors)

\begin{tabular}{|l|c|c|c|c|c|c|}
\hline $\begin{array}{l}\text { Thoroughness of reading the annual } \\
\text { report (General Investors) }\end{array}$ & $\mathrm{N}$ & $\mathrm{Mean}$ & $\mathrm{t}$ & $\begin{array}{c}\text { Df (degrees } \\
\text { of freedom) }\end{array}$ & $\begin{array}{c}\text { Sig. } \\
\text { (2-tailed) }\end{array}$ & $\begin{array}{c}\text { Statistical } \\
\text { Significance }\end{array}$ \\
\hline Company's information & 30 & 2.73 & $\mathbf{- 1 . 2 5}$ & 29 & $\mathbf{0 . 2 2}$ & Not Significant \\
\hline Chairman's review & 30 & 2.50 & $\mathbf{- 2 . 3 5}$ & 29 & $\mathbf{0 . 0 3}$ & Significant \\
\hline Director's Report & 30 & 2.53 & $\mathbf{- 2 . 0 4}$ & 29 & $\mathbf{0 . 0 5}$ & Significant \\
\hline Corporate Governance Statement & 30 & 2.57 & $\mathbf{- 1 . 7 8}$ & 29 & $\mathbf{0 . 0 9}$ & Not Significant \\
\hline Audit Committee Report & 30 & 2.97 & $\mathbf{- 0 . 1 4}$ & 29 & $\mathbf{0 . 8 9}$ & Not Significant \\
\hline Auditor's Report to shareholders & 30 & 3.07 & $\mathbf{0 . 2 9}$ & 29 & $\mathbf{0 . 7 7}$ & Not Significant \\
\hline Balance Sheet & 30 & 3.77 & 3.36 & 29 & $\mathbf{0 . 0 0}$ & Significant \\
\hline Income Statement & 30 & 3.87 & $\mathbf{4 . 5 6}$ & 29 & $\mathbf{0 . 0 0}$ & Significant \\
\hline Statement of Changes in Equity & 30 & 3.37 & $\mathbf{1 . 7 3}$ & 29 & $\mathbf{0 . 0 9}$ & Not Significant \\
\hline Cash flow Statement & 30 & 3.23 & $\mathbf{1 . 1 0}$ & 29 & $\mathbf{0 . 2 8}$ & Not Significant \\
\hline Accounting Policy notes & 29 & 2.52 & $\mathbf{- 2 . 1 4}$ & 28 & $\mathbf{0 . 0 4}$ & Significant \\
\hline Balance Sheet notes & 30 & 2.90 & $\mathbf{- 0 . 4 0}$ & 29 & $\mathbf{0 . 6 9}$ & Not Significant \\
\hline Income Statement notes & 30 & 2.77 & $\mathbf{- 0 . 9 8}$ & 29 & $\mathbf{0 . 3 4}$ & Not Significant \\
\hline Cash flow Statement notes & 29 & 2.48 & $\mathbf{- 2 . 1 4}$ & 28 & $\mathbf{0 . 0 4}$ & Significant \\
\hline Value Added Statement & 29 & 2.24 & $\mathbf{- 3 . 4 5}$ & 28 & $\mathbf{0 . 0 0}$ & Significant \\
\hline Environmental Report & 28 & 2.00 & $\mathbf{- 5 . 0 2}$ & 27 & $\mathbf{0 . 0 0}$ & Significant \\
\hline 3 or 5-year reviews (including useful ratios) & 29 & 3.41 & $\mathbf{1 . 5 4}$ & 28 & $\mathbf{0 . 1 4}$ & Not Significant \\
\hline Essay and pictorial on operations & 27 & 2.11 & $\mathbf{- 3 . 8 9}$ & 26 & $\mathbf{0 . 0 0}$ & Significant \\
\hline
\end{tabular}

General investors read the Balance Sheet and Income Statement more thoroughly than any other components of annual reports.

Table 17: Thoroughness of reading the annual report

\begin{tabular}{|l|c|c|c|c|c|c|}
\hline $\begin{array}{l}\text { Thoroughness of reading the annual } \\
\text { Report (Stock Broker) }\end{array}$ & $\mathrm{N}$ & Mean & $\mathrm{t}$ & $\begin{array}{c}\text { Df (degrees } \\
\text { of freedom) }\end{array}$ & $\begin{array}{c}\text { Sig. } \\
\text { (2-tailed) }\end{array}$ & $\begin{array}{c}\text { Statistical } \\
\text { Significance }\end{array}$ \\
\hline $\begin{array}{l}\text { Company's objective, mission, and vision } \\
\text { statements, company info. }\end{array}$ & 7 & 3.86 & $\mathbf{1 . 5 5}$ & 6 & $\mathbf{0 . 1 7}$ & Not Significant \\
\hline Chairman's review & 8 & 3.75 & $\mathbf{1 . 8 2}$ & 7 & $\mathbf{0 . 1 1}$ & Not Significant \\
\hline Director's Report & 8 & 3.38 & $\mathbf{0 . 8 9}$ & 7 & $\mathbf{0 . 4 0}$ & Not Significant \\
\hline Corporate Governance Statement & 6 & 3.83 & $\mathbf{2 . 0 8}$ & 5 & $\mathbf{0 . 0 9}$ & Not Significant \\
\hline Audit Committee Report & 8 & 4.00 & $\mathbf{2 . 0 0}$ & 7 & $\mathbf{0 . 0 9}$ & Not Significant \\
\hline
\end{tabular}




\begin{tabular}{|l|c|c|c|c|c|c|}
\hline Auditor's Report to shareholders & 8 & 4.62 & $\mathbf{6 . 1 8}$ & 7 & $\mathbf{0 . 0 0}$ & Significant \\
\hline Balance Sheet & 8 & 4.62 & $\mathbf{6 . 1 8}$ & 7 & $\mathbf{0 . 0 0}$ & Significant \\
\hline Income Statement & 8 & 4.62 & $\mathbf{6 . 1 8}$ & 7 & $\mathbf{0 . 0 0}$ & Significant \\
\hline Statement of Changes in Equity & 7 & 3.71 & $\mathbf{1 . 2 6}$ & 6 & $\mathbf{0 . 2 5}$ & Not Significant \\
\hline Cash flow Statement & 7 & 4.14 & $\mathbf{2 . 0 7}$ & 6 & $\mathbf{0 . 0 8}$ & Not Significant \\
\hline Accounting Policy notes & 7 & 2.43 & $\mathbf{- 1 . 9 2}$ & 6 & $\mathbf{0 . 1 0}$ & Not Significant. \\
\hline Balance Sheet notes & 8 & 3.88 & $\mathbf{2 . 9 7}$ & 7 & $\mathbf{0 . 0 2}$ & Significant \\
\hline Income Statement notes & 8 & 3.62 & $\mathbf{2 . 3 8}$ & 7 & $\mathbf{0 . 0 5}$ & Significant \\
\hline Cash flow Statement notes & 8 & 3.25 & $\mathbf{0 . 5 5}$ & 7 & $\mathbf{0 . 6 0}$ & Not Significant \\
\hline Value Added Statement & 8 & 3.25 & $\mathbf{0 . 5 1}$ & 7 & $\mathbf{0 . 6 3}$ & Not Significant \\
\hline Environmental Report & 8 & 2.75 & $\mathbf{- 0 . 5 5}$ & 7 & $\mathbf{0 . 6 0}$ & Not Significant \\
\hline 3 or 5-year reviews (including useful ratios) & 7 & 3.71 & $\mathbf{1 . 7 0}$ & 6 & $\mathbf{0 . 1 4}$ & Not Significant \\
\hline Essay and pictorial on operations & 7 & 2.71 & $\mathbf{- 0 . 4 4}$ & 6 & $\mathbf{0 . 6 7}$ & Not Significant \\
\hline
\end{tabular}

Stockbrokers read Auditor's Report to shareholders, Balance Sheet, Income Statement, Balance Sheet notes, and Income Statement notes more thoroughly than any other components of annual reports.

\section{Conclusion AND ReCOMmEndATIONS}

Based on the outcomes of this study, the following conclusions were reached:

The general investors do not read annual reports for decision making. However, the stockbrokers read annual reports for decision making. The general investors consider company annual reports, newspaper news, and media reviews as some of the most vital sources of information. Stockbrokers consider Company Annual Report, Interim Report, Newspaper and media, Stock market publication, Technical analysis as important sources of information. It has been found that to the most significant components of the annual report are Audit Committee Report, Balance Sheet, Income Statement, and Statement of Changes in Equity, 3 or 5-year reviews (including useful ratios) from the general investor's perspectives. To the stockbrokers, the most essential components of the annual report are Auditor's Report to shareholders, Balance Sheet, Income Statement, and Balance Sheet notes. It has also been established that general investors read the Balance Sheet and Income Statement more thoroughly than any other components of annual reports. Stockbrokers read Auditor's Report to shareholders, Balance Sheet, Income Statement, Balance Sheet notes, and Income Statement notes more thoroughly than any other components of annual reports.

Based on the outcomes of this study, the following recommendations can be proposed:

- Necessary steps should be taken to increase the attendance of the general investors in training. The outcomes showed that most of the respondents were not having any training. Moreover, training influences how the users emphasize and use different sources of information and different components of annual reports.

- Accounting and Finance courses should be more practical and stock market oriented. The outcomes showed that accounting and finance courses were not able to make major differences among the users' assessment of the importance of the sources of information and the importance of the components of the annual report.

- We expected that the importance and level of reading Auditor's Report to shareholders will be higher to the general investors. However, the outcomes showed otherwise. It indicates the lack of confidence of the general investors on auditor's report. Thus, the audit profession should come forward to improve their image to the general investors.

\section{ACKNOWLEDGMENT}

At the very beginning, we would like to thank, the Almighty, without whose blessings, this work would not have been possible and successful. Our heartfelt gratitude goes to our parents for their love, prayers, dedication, and sacrifices in educating and preparing us for my future. Finally, we would like to thank the voluntary participants who helped us in completing this work by providing their valuable responses in the questionnaire. In the end, we would like to thank our colleagues for their candid support and valuable suggestions for completing this work.

\section{REFERENCES}

Abu-Nassar, M., \& Rutherford, B. A. (1996), "External Users of Financial Reports in Less Developed Countries: The Case of JORDAN," The British Accounting Review, vol. 28, no. 1, pp. 73-87.

Alattar, J. M., \& Al-Khater, K. (2008), "An empirical investigation of users' views on corporate annual reports in Qatar," International Journal of Commerce and Management, vol. 17, no. 4, pp. 312-325.

Al-Razeen, A., \& Karbhari, Y. (2004), "Annual corporate information: Importance and use in Saudi Arabia," Managerial Auditing Journal ,vol. 19, no. 1, pp. 117-133.

Anderson, R., \& Epstein, M. (1995), "The usefulness of annual reports," Australian Accountant, pp. 25-28. 
Anwar, F., Anwar, S., \& Mannan, A. (2012), "The Relevance of Annual Reports - The Use of Annual Reports in Investment and Finance Decisions in a Developing Country," International Conference on Business Management $\mathcal{E}$ IS., vol. 1.

Baker, H. K., \& Haslem, J. A. (1973), "Information Needs of Individual Investors," Journal of Accountancy, pp .64-69.

Day, J. F. (1986), "The Use of Annual Reports by UK Investment Analysts", Accounting and Business Research, vol. 16, no. 64, pp. 295-307.

Kitindi, E., Magembe, B., \& Sethibe, A. (2007), "Lending Decision Making and Financial Information: The Usefulness of Corporate Annual Reports to Lenders in Botswana, "The International Journal of Applied Economics and Finance, vol. 1, no. 2, pp. 55-66.
Lee, T. A., \& Tweedie, D. P. (1975), "Accounting Information: An Investigation of Private Shareholder Usage," Accounting and Business Research, vol. 5, no. 20, pp 280-291.

Magness, V. (2003), "Economic values and corporate financial statements," Environmental Management , vol.32, no. 1, pp. 111.

Naser, K., Nuseibeh, R., \& Al-Hussaini, A. (2003), "Users' perceptions of various aspects of Kuwaiti corporate reporting", Managerial Auditing Journal, vol. 18, no. 7, pp. 599-617.

Yap, C. (1997), "Users' perceptions of the need for cash flow statements - Australian evidence," Europian Accounting Review, vol. 6, no. 4, pp. 653-672.

$--0--$ 